\title{
Roots of Alexithymia
}

\author{
Daniela Šago 1, 2 , Goran Babić3, 4 \\ ${ }^{1}$ Psychiatric Hospital 'Sveti Ivan', Zagreb, Croatia, ${ }^{2}$ Faculty of Medicine, Josip Juraj Stross- \\ mayer University of Osijek, Osijek, Croatia ${ }^{3}$ Croatian Psychoanalytic Society, Zagreb, \\ Croatia, ${ }^{4}$ University of Zagreb, School of Medicine, Zagreb, Croatia
}

\begin{abstract}
This paper presents the historical background and theoretical framework of alexithymia and the development of the instruments that measure this theoretical construct more accurately. The alexithymia concept was derived from clinical observation, initially formulated without an underlying theoretical framework. Nowadays, alexithymia is a part of the theory of cognitive processing and regulation of emotions. The paper also reviews the interest alexithymia aroused in research and clinical work of various fields of psychology, particularly psychoanalysis. The concept was developed from clinical experience with psychosomatic patients that responded poorly to psychotherapy. The development of the concept from categorical to dimensional is highlighted. Alexithymia was conceptualised as a defense mechanism, but also as deficit pathology. It overlaps with the concept of mentalization and can be viewed both in terms of state and trait features. Finally, the measuring instruments for alexithymia are comprehensively listed.
\end{abstract}

Keywords: alexithymia, psychoanalytic theory, psychosomatic disorder, the theory of mind, mentalizing

\section{Historical background and theoretical framework of the alexithymia concept}

The term alexithymia (Greek; a = lack, lexis $=$ word, thymos $=$ emotion, mood, or feeling) was coined by Sifneos and introduced in the early 1970s to denote a cluster of features including difficulty identifying and describing subjective feelings, a restricted fantasy life, and preoccupation with trivial aspects of external events' characteristics [1].

Correspondence to: Daniela Šago

Psychiatric Hospital 'Sveti Ivan', Jankomir 11, 10090 Zagreb, Croatia

Phone: +385-91-3211500; E-mail: sago.daniela@gmail.com
Clinical observation of alexithymia date back to the 1940s [2]. Alexithymic deficits were described in patients with classic psychosomatic diseases as well as in general psychiatric patients, particularly in those responding poorly to psychoanalytic therapy [3-6]. Reusch described affective and cognitive disturbance due to developmental arrest in early childhood when emotions are not well connected with words and expressed through bodily channels [3], while Kelman associated externalized living as modus vivendi [6]. Marty and de M'Uzan's [7] introduce a concept of pensée opératoire (operative thinking), denoting the absence of fantasy and other manifestation of the depleted inner mental world 
of feelings, ideas about intentions, needs, attitudes and focused on external events. They also suggested a vulnerability to somatic illness. Marty [8, 9] attributed it to a deficiency in mentalization - a concept introduced in the early 1960s. Almost simultaneously, Krystal independently described similar observations among patients with substance use disorders and posttraumatic states [10, 11]. Krystal first highlighted alexithymia as possibly the most critical single factor diminishing the success of psychoanalysis [12]. Rubins emphasized that Horney was the first to label these patients as alexithymic [5, 13]. McDougall referred to these individuals as normopaths, dis-affected and anti-analysands, and she warned of prolonged periods of stagnation in therapy [14-16]. In 1967 Sifneos reported his preliminary observations on some patients' distress from psychosomatic illnesses [16]. He recognized that they have no pathology of conflict as neurotic patients have, but rather show deficits in the ability to experience feelings. In the subsequent three years, Nemiah and Sifneos conducted a more systematic examination of previously tape-recorded interviews of patients with two of the following classic psychosomatic diseases specified by Alexander (duodenal ulcer, bronchial asthma, rheumatoid arthritis, ulcerative colitis, hypertension, hyperthyroidism, and atopic dermatitis) [17-19]. Their conclusion was that these patients have difficulty in describing and identifying their feelings. Also, many of these patients showed a thought content consistent with the concept of pensée opératoire. In the seminal publication, Nemiah, Freyberger, and Sifneos fully explicated core features of alexithymic individuals [20]. The year 1976 was defining for the alexithymia construct, when it was selected as the central theme of the 11th Euro- pean Conference on Psychosomatic Research in Heidelberg, Germany. At the meeting, Sifneos told attendees that 'The word was simply used to describe certain clinical observations that were made over very many years. I tried appropriately to use a Greek word or a pseudo-Greek word for descriptive purposes' [21]. Alexithymia engulfs a disturbance in affective and cognitive functions and is characterized by a difficulty recognizing and verbalizing feelings, and a paucity of fantasy [1]. Nemiah and colleagues made the distinction between emotions and feelings [21]. Emotions have the neurophysiological component and the component of motor-expression of affect. Both components must have mental representations before the conscious experience of feelings [20]. More recently Damasio emphasized the same conceptual distinction and highlighted that emotions precede feelings [22]. Sifneos and Nemiah pointed out that alexithymia is not an absence of emotions, but rather a deficit in elaborating feelings [16]. Nemiah, Freyberger and Sifneos also reported that 'Although many individuals may initially speak of being nervous, or sad, or angry, if they are pressed to describe their feelings further and to tell the examiner what being sad or nervous or angry feels like, it rapidly becomes apparent that they are totally unable to do so' [20]. Many psychoanalysts and psychotherapists observed that those patients are deficient in specific psychological capacities and do not respond well to traditional interpretative psychotherapies [5, 6, 23].

\section{Lack of love, joy, and happiness}

We can imagine an alexithymic person as an individual who lacks psychological mindedness, demonstrates a minimal interest in play and has concreteness in dreaming and thinking; someone who has limited aware- 
ness of emotions and drives, and a utilitarian style of living, whose behavior is guided by rules instead of inner feelings, fantasies, and wishes. When attending psychoanalytic therapy, an alexithymic individual fills the session with a monotonous chronological recital of external events and is unable to engage in psychotherapeutic therapy, provoking feelings of dullness and boredom in the therapist. Hence, it is very likely that alexithymia will be associated with less improvement in psychotherapy [24]. The alexithymic individual has a limited ability to experience pleasurable emotions such as joy, love, and happiness [25, 26]. Krystal conceptualized the course of maturation of emotions as a progressive desomatisation also linked to learning of words and subsequently differentiated into different subjective feelings [27]. Furthermore, the failure to link feelings with fantasies and to reflect on inner experience pushes the mind toward a preoccupation with the details of external events, which is characteristic of pensée opératoire [28]. With alexithymia, the emotions are still felt, but the connections with words and images are interrupted, the emotions are poorly represented at higher levels of consciousness, resulting in a deficit of conscious feelings and difficulties in identifying and verbalizing feelings. It is likely that individuals with difficulty identifying, verbalizing, and reflecting on feelings would be inclined to greater emotional arousal in response to emotional stimuli [29]. Individuals with alexithymic deficits can have outbursts of sadness or rage, which may seem to be at odds with the definition, but they have no understanding of these strong emotional expressions [30].

\section{Alexithymia and the concept of mentalization}

During the 1960s in an attempt to understand the role of pensée opératoire in psychosomatic illness, the French psychosomatic school introduced the concept of mentalization [8, 9, 31]. During the 1990s, Lecours and Bouchard extended the contributions of Marty and other French analysts by proposing a hierarchical conceptual model with levels of mentalization which shows some similarities to Krystal's theory of affects and Lane and Schwartz's hierarchical model of levels of emotional awareness [28, 32, 33]. It was around that time when Fonagy and Target adopted the concept of mentalization and defined it more broadly as the capacity to think about one's own and others' mental states regarding feelings, desires, and intentions [34, 35]. More recently, Fonagy, Bateman and Luyten described mentalization as a multifaceted construct with cognitive and affective components and indicated that mentalizing is not granted and constant capacity of the mind, but is in constant flux and dynamic and interplay context of specific attachment relationships is also influenced by the level of distress in specific moments [36]. According to Taylor and Bagby the way that Fonagy understands mentalization [36], and the way Lane applies it, is very different from how it was conceptualized originally by French psychoanalysts $[8,9,23,31,36,37]$. Lane and colleagues argue that scientific developments since the 1970s, including the concept of 'theory of mind' or mentalization, make it essential to expand the alexithymia concept [38]. He permits a shift to a perspective that difficulty in verbalizing is the indicator, not the cause of the problem. Vanheule and colleagues also have highlighted that alexithymia is an indicator of an underlying process [39, 40]. While Taylor, Bagby, and Parker argue that alexithymia does not embrace the cognitive aspects of broad mentalization construct, the authors of this paper 
see externally oriented thinking as a teleological stance which is a developmental stage in mentalization [41]. Teleological stance/mode is extreme exterior focused thinking in which only observable change or action is considered to be a valid indicator of the intentions of others [42]. Lane and colleagues report that the Levels of Emotional Awareness Scale (LEAS) correlated positively with some measures of 'theory of mind', which is not the case with the Toronto Alexithymia Scale [37]. Some individuals with a high degree of alexithymia might be impaired in their ability to read the intentions, desires, and emotional states of others, but measures of alexithymia were not designed to assess this ability [43]. Several researchers have found associations between alexithymia and poor empathic abilities, which is consistent with clinical observations and suggests that impaired empathy is a correlate of alexithymia [28,44-46].

\section{Dimensional or categorical construct?}

While Lane and colleagues proposed two subtypes of alexithymia anomia (lack of words for emotions) and agnosia (not knowing one's emotions), Primmer suggested various degrees of alexithymia [37, 47]. The concept of affective agnosia is a cue that alexithymia is not merely a difficulty in finding words for feelings, but involves a deficiency in the mental representation of emotions [37]. Contrary to Nemiah and Sifneos, Krystal regarded alexithymia as a dimensional construct and reported that 'Most patients are able to experience some feelings some of the time' and stated that alexithymia is not an 'all or nothing' manifestation [28]. It is possible that the same individuals with alexithymia might express fluctuations in their level of emotional awareness and they shift back and forth on the continuum between affective agnosia and anomia proposed by Lane and colleagues [37]. Following Krystal's ideas about the impact of trauma on affect development and affect regression, the degree of alexithymia in a person is likely to reflect the extent of trauma experienced by the person during childhood or as an adult, and whether or not an attachment figure was available to contain and modulate the person's distress [48]. Contemporary theory and research of alexithymia suggest continuous rather than categorical approach, as it often includes trait and state components alike [37, 47, 49-52]. The empirical results of different studies provided substantial finding for viewing alexithymia as a dimensional construct, as well as findings from several different taxometric investigations [23, 50, 51].

\section{Primary versus secondary alexithymia}

A distinction between primary and secondary alexithymia was made in the last century [53]. Primary alexithymia was thought to reflect 'structural or neurobiological defects' and secondary or acquired alexithymia was seen as emerging from 'developmental arrests or from a catastrophic environmental onslaught', or a reaction to life-threatening illness or medical treatment $[25,54]$. Secondary alexithymia is thus amenable to change when the medical illness or life setting improves [55-57]. Taylor, Bagby, and Parker have pointed out that alexithymia is the name of the multifaceted construct, and regardless of etiology, is not only a difficulty in finding words for emotional feelings or emotional non-expression in the face of situational stressors that clears when stress decreases [41].

\section{Defense mechanism}

Several psychoanalysts advocated that alexithymia is ego defense or immature defense mechanism against anxiety and under- 
lying neurotic conflicts $[5,6,58-60]$. On the contrary, Krystal argued that alexithymia is a defense in a teleological sense only, as it is an arrest in affective and cognitive development [61]. McDougall reconciled with the proposed explanation that defense theory and the deficit/developmental arrest theory are not mutually exclusive $[62,63]$. Her theory depicts alexithymia as a massive defense against primitive dreads and overwhelming pain rather than neurotic anxieties. Other authors perceive alexithymia as massive defense against intolerable emotions as well as a deficit in the mental representation of emotions, or as a diminished capacity for imagination and mental representation of emotions [23, $33,58,64]$.

\section{State and trait features}

Empirical findings demonstrate that although alexithymia is a trait, it shows some state variation as a reaction to the presence of illness [23, 49, 65]. Patients affected by panic disorder might resolve the alexithymic reaction only after remission when symptom severity returned to the premorbid level [66]. This supports the hypothesis of alexithymia as a personality trait with state characteristics which wax and wane together [66]. Fonagy P., Bateman A., and Bateman A. emphasize that in contrast to alexithymia, mentalization is not a static and unitary skill or trait but a dynamic capacity [67]. Several studies have shown lack of absolute stability of alexithymia, although generally speaking, an individual's degree of alexithymia is fairly constant in clinical situations and other interpersonal contexts [65, 68, 69].

\section{Instruments developed to assess alexithymia}

Since the concept of alexithymia was introduced as a coherent construct, several re- searchers have attempted to develop reliable and valid instruments for its measuring. Many of observer-rated questionnaires, self-report scales, and projective techniques are available, but most of these with poor psychometric properties [70]. Haviland has given a detailed overview of the instruments for measurement of alexithymia by enlisting them as selfreport, structured interview, semi-structured interviews, observer reports, projective test, and self-report / rater scored [71].

Most researchers agree that clinically observable features of alexithymia consist of four salient components (restricted imaginal process included), even though the widely used measurement of alexithymia, Toronto alexithymia scale (TAS-20), consists of three subscales [20]. Vorst and Bermond included impaired capacity for experiencing feelings of emotion as the fifth component of the alexithymia concept [72]. Some researchers have suggested fantasizing and emotionalizing as correlates rather than prominent constituents of the alexithymia construct, while others have proposed externally oriented thinking (EOT) subscale substantially different than difficulty identifying feelings (DIF), and difficulty describing feeling (DDF) subscales $[73,74]$. Some of these topics were explored recently, and it has been suggested that restriction of imaginal capacity might be a less salient component of the alexithymia construct [75]. The same study supported pensée opératoire as a salient component of the alexithymia construct which might be adequately assessed by the EOT subscale [75]. For decades, the concept of alexithymia has challenged discussion concerning facets that constitute this construct, which is reflected in the subscales of different instruments for measuring alexithymia [29]. Nevertheless, empirical research is challenging to 
address the complexity of the multifaceted alexithymia construct. Measurement of alexithymia has been proven as problematic in the clinical and nonclinical sample [76].

Some of the earlier instruments for measuring alexithymia reflect the duality of theoretical perspectives and categorize individuals into those with and without alexithymia, such as the first instrument for measurement of alexithymia Beth Israel Hospital Psychosomatic Questionnaire (BIQ), or interviewbased Diagnostic Criteria for Psychosomatic Research, Alexithymia (DCPR-A) [77]. DCPR-A assesses 12 psychosocial syndromes clustered into five diagnostic areas, one of which is alexithymia with difficulties verbalizing and communicating emotional states, reduced fantasy, external thinking, physical reactions to strong emotions; outburst of anger, crying, or joy [78]. BIQ, as well as Alexithymia Provoked Response Questionnaire (APRQ) and Karolinska Psychodynamic Profile (KAPP) are assessment scales to be used with an interview [79, 80].

Some authors suggest that self-report scales do not reliably assess individuals with a high degree of alexithymia, who may lack the introspective capacity to accurately evaluate their difficulty in identifying and describing subjective feelings [54, 81, 82]. The Shipko and Noviello Alexithymia Scale (SNALEX) lacks construct validity as a measure of alexithymia in psychiatric patients [83]. Twentytwo item MMPI Alexithymia Scale was developed in Denver from the first 556 items derived from Beth Israel Psychosomatic Questionnaire (BIQ) and is supposed to have more stability over time [84]. Unfortunately, MMPI Alexithymia Scale as well as the original and revised versions of the Schalling-Sifneos Personality Scale (SSPS)lack validity and have poor internal reliabilities [74, 85-87].
The Amsterdam Alexithymia Scale (AAS) is a self-report questionnaire covering five essential features of alexithymia and encompasses fantasizing and analyzing emotions [88]. Sifneos developed previously mentioned observer-rated BIQ, but with lack of adequate interrater reliability [41, 89]. Following suggestions of Sriram, Taylor and Bagby developed a modified version for measuring alexithymia with six items that assess affect awareness and six items that assess operative thinking $[30,90]$. The same authors gave the most significant contribution to the development of instruments for measuring alexithymia. Nowadays, Modified-BIQ is used only occasionally. Later, they developed the Toronto Structured Interview for Alexithymia (TSIA) which is a more reliable method then self-report question measurement [91]. Measuring alexithymia with structured interview method assesses the imaginal processes, although the items may not adequately capture wish fulfillment imaginations and fantasies, which was the content emphasized by Krystal, and Nemiah, Freyberger and Sifneos [20, 92]. The TSIA consists of 24 interview questions distributed across four sixitem subscales and includes a separate subscale for measuring the fantasizing facet over the three facets also assessed by the TAS-20 [50]. The TSIA correlates positively with the TAS-20 in a variety of samples [91]. Rorschach Reality-Fantasy Scale (RFS) or Rorschach Alexithymia Scale (RAS) represent an alternative method for assessing the creation, imaginal capacity and potential space between reality and fantasy [93-96]. The Scored Archetypal Test (SAT9), similarly to Rorschach, uses projective instruments to measure the degree of alexithymia [97]. The California Q-set Alexithymia Prototype (CAQ-AP), an observer- and a self-report 
measure of the alexithymia construct, compares to which extent the alexithymia is determined either by the patient or by an observer [98-100]. Nemiah, who actively participated in the construction of this instrument, stated that CAQ-AP seems to provide the most accurate and complete description of alexithymia, as it was initially derived from clinical observation [71]. Observer Alexithymia Scale (OAS) is a self-report questionnaire to be completed by a subject's acquaintance or a relative and has 33-items based on a five-factor structure: distant, uninsightful, somatizing, humorless, and rigid [101]. Lane and Schwartz proposed a complex hierarchical model of cognitive-emotional development which can be assessed with the self-report instrument Levels of Emotional Awareness Scale (LEAS) [33,102]. Although the LEAS may adequately assess the levels of emotional awareness construct and the continuum of increasing cognitive complexity, and can also distinguish between affective agnosia and anomia, it 'was not created as a measure of alexithymia per se' [82], and was recently described simply as 'a performance measure of the ability to put emotions into words' [38, 82, 102]. The recent meta-analytic review has shown a small overlap between LEAS and TAS-20 [103]. The self-report Bermond-Vorst Alexithymia Questionnaire (BVAQ) was developed to improve assessment of the salient features of alexithymia as a diminution of fantasy [72]. Vorst and Bermond view emotionalizing as a fundamental personality dimension that falls outside of the alexithymia construct [72]. However, recent network analysis of the BVAQ did not support emotionalizing as a distinct component of the alexithymia construct [29]. Recognizing the limitations of existing measures, the Toronto Alexithymia
Scale (TAS) was developed with concern for empirical and theoretical congruence with the alexithymia construct. It encompasses five different features of alexithymia including lack of introspection, social over adaptation, and limited fantasy life together with difficulties remembering dreams [104]. Initially, it had 41 items. Half of these items were phrased negatively, to compensate answering tendencies and at the end, only 26 were retained. Fifteen items had to be dropped due to low correlations [105]. The resulting scale with 26 items comprising the TAS was clustered into a four-factor structure and covered diminished daydreaming (supposed to represent a limited fantasy life). In the available literature, we have found it as the original 26-item TAS whichis still used worldwide [104, 106]. In subsequent studies, the TAS-26 was found to have some psychometric shortcomings such as social desirability, a high number of items measuring diminished daydreaming, and low item correlation, also the daydreaming factor correlated negatively with the first factor and had little theoretical coherency in the alexithymia construct. The authors of the scale suggest that self-report assessment of daydreaming activity is confounded by a social desirability response bias and may not adequately capture the capacity for imaginal activities [70]. They also added that the compositional structure of the TAS-26 does not represent the separate domains equally. So they decided to develop an improved and revised version TAS-R where all items assessing daydreaming were eliminated [26]. In the first revision, TAS-R had 23 items and a two-factor structure with DDF and DIF items tending to collapse into one single component $[70,105]$. In the second revision they added 17 new items, and at the end, 20 items were included in TAS-20 
consisting of three factors DIF, DDF, and EOT. It was considered as being independent from the socially desirable answers. In empirical studies, the TAS-20 is widely used as a measurement for alexithymia construct because of its supposed good psychometric properties [105,107]. TAS-20 provides a dimensional and categorical assessment of the alexithymia features. It incorporates empirically derived cutoff scores as well as scores ranging from 20 to 100 . The TAS-20 has been translated into more than twenty languages and has been cross-validated by confirmatory factor analysis in Western, Eastern European, East Asian, and Middle Eastern countries [108-112]. These findings support the view of alexithymia as a universal trait rather than a culture-bound construct. The TAS-20 indirectly assesses imaginal processing of alexithymia by the EOT subscale, even though this subscale correlates negatively with measures of fantasy [113, 114]. The omission of an explicit assessment of imaginative processes may produce issues of 'noise' and unreliable responding that is assumed to be associated with the self-report method or the weakest point of a chain of TAS-20 measurement [50]. Kooiman, Spinhoven, and Trijsburg highlight unsatisfactory low internal consistency of the EOT factor and low test-retest reliability for DDF and EOT subscales [105]. They also noted that TAS-20 assesses some, but not the fantasy aspect of alexithymia. Their opinion is to use the TAS-20 in empirical research combined with some other instruments for alexithymia [105]. Similar viewpoint have Rokvić and Jovanović who suggest a modification of the EOT subscale [115]. Although TAS-20 authors recommend using total TAS-20 scores, researchers often calculate total and subtotal scores and evaluate all relationships with ex- ternal correlates [71]. Many studies found that the TAS-20 weakly correlated with older age, male sex, lower socioeconomic status and fewer years of education [82]. The common limitations of the self-report method are poor self-insight as alexithymic patients usually are not very self-reflective, dissemblance and various response styles, as well as poor comprehension of some of the respondents [105, 116-118]. One of the possible TAS-20 limitations is that highly alexithymic individuals cannot accurately assess their deficits in affect awareness due to lack of insight [23]. Lane and colleagues added an inherent difficulty with the use of self-reports to measure, and that is the reason why authors recommend using more than one method when assessing alexithymia [30, 43, 50]. Vanheule noted that asking a person if he or she is unaware of his or her feelings is to a certain extent paradoxical and therefore, measuring alexithymia by self-report is problematic [119]. On the other hand, Taylor, Bagby, and Parker yielded good results regarding construct validity and endorsed TAS-20 as a valid measure of the alexithymia construct $[41,107]$.

\section{Limitations}

In this review we focused on the historical background and theoretical framework of the alexithymia construct and the instruments developed to assess alexithymia. Due to the abundance of theoretical and empirical knowledge on the alexithymia construct, we could not encompass the genetic and environmental/developmental factors in the etiology of alexithymia, as well as attachment theory, childhood trauma and all other factors that distress the development and affect regulation. We have to acknowledge the 
common limitations of narrative versus systematic literature review as a potentially biased source and selection of literature, less evidence-based inferences as well as qualitative analysis instead of quantitative synthesis.

\section{Conclusion}

Alexithymia is not classified as a mental disorder in DSM-5. Nevertheless, it is accepted that alexithymia has a negative impact on a variety of somatic and mental health treatments. The recent review 'The relationship between alexithymia and morbidity' listed many somatic and mental disorders and their

\section{References}

1. Sifneos P. The prevalence of 'alexithymic' characteristics in psychosomatic patients. Psychother Psychosom 1973;22:255-62.

2. Padmanabhan JL, Keshavan MS. Schizophrenia. In: Encyclopedia of Mental Health. Elsevier; 2016. p. 55-65.

3. Ruesch J. The infantile personality. The core problem of psychosomatic medicine. Psychosom Med. 1948;10:134-44.

4. Maclean PD. Psychosomatic disease and the visceral brain; recent developments bearing on the Papez theory of emotion. Psychosom Med 1949;11:33853.

5. Horney K. The paucity of inner experiences. Am J Psychoanal. 1952;12:3-9.

6. Kelman N. Clinical aspects of externalized living. Am J Psychoanal. 1952;12:15-23.

7. Marty, P, de M'Uzan M. La 'pensee operatoire'. Rev Fr Psychanal. 1963;1345-56.

8. Marty P. Mentalization et Psychosomatique. Paris: Laboratoire Delagrange; 1991.

9. Fain M, Marty P. Psychosomatic view of the function of the phantasms. Rev Fr Psychanal. 1964;28:609-22. connection with the alexithymia construct [120]. Alexithymia is an intriguing topic and has generated a large body of research in the past 40 years. Debates about the definition and measurement of alexithymia continue even though its etiology has not been firmly established [71].

\section{Acknowledgements}

None.

\section{Conflicts of interest}

None to declare.

10. Krystal H. Massive psychic trauma. New York: NY: International Universities Press. 1968.

11. Krystal H, Ruskin H. Drug dependence. Detroit: MI: Wayne State University Press. 1970.

12. Krystal H. Alexithymia and the effectiveness of psychoanalytic treatment. Int J Psychoanal Psychother. 1982;9:353-78.

13. Rubins JL. On cognition, affects, and Horney theory. Am J Psychoanal. 1980;40:195-212.

14. McDougall J. The anti-analysand in analysis. In: Lebovici S, Widlöcher D, editors. Ten years of Psychoanalysis in France. New York: International Universities Press; 1972. p. 333-54.

15. McDougall J. The 'dis-affected' patient: reflections on affect pathology. Psychoanal Q. 1984;53:386409.

16. Sifneos PE. Clinical observations on some patients suffering from a variety of psychosomatic diseases. Acta med Psychosom. 1967;7:3-10.

17. Nemiah JC, Sifneos PE. Psychosomatic illness: a problem in communication. Psychother Psychosom 1970;18:154-60.

18. Alexander F. The development of psychosomatic medicine. Psychosom Med 1962;24:13-24.

19. Alexander F. Psychosomatic medicine. Its principles and applications. Norton, New York; 1950. 300 p. 
20. Nemiah JC, Freyberger H, Sifneos PE. Alexithymia: A view of the psychosomatic process. In: Hill OW, editor. Modern Trends in Psychosomatic Medicine, volume 3. London: Butterworths, London; 1976. p. 430-9.

21. Sifneos PE. Comments in panel- and plenum discussion: Psychotherapeutic problems with psychosomatic patients. In: Brautigam W, von Rad M, editors. Toward a Theory of Psychosomatic Disorders Alexithymia, Pensée Opératoire, Psychosomatisches Phänomen Proceedings of the 11th European conference on psychosomatic research. Karger, Basel; 1977. p. 361-75.

22. Damasio A. Looking for Spinoza: Joy. Sorrow, and the Feeling Brain. Harcourt, Orlando; 2003.

23. Taylor GJ, Bagby RM. Psychoanalysis and empirical research: the example of alexithymia. J Am Psychoanal Assoc. 2013;61:99-133.

24. Ogrodniczuk JS, Piper WE, Joyce AS. Effect of alexithymia on the process and outcome of psychotherapy: a programmatic review. Psychiatry Res. 2011;190:43-8.

25. Sifneos PE. Anhedonia and alexithymia: A potential correlation? In: Clark DC, Fawcett J, editors. Anhedonia and Affect Deficit States. New York, NY: PMA Publishing Corporation; 1987. p. 19927.

26. Taylor GJ. Psychoanalysis and empirical research: the example of patients who lack psychological mindedness. J Am Acad Psychoanal. 1995;23:26381.

27. Krystal H. Aspects of affect theory. Bull Menninger Clin; 1977.

28. Krystal H. Alexithymia and psychotherapy. Am J Psychother. 1979;33:17-31.

29. Watters CA, Taylor GJ, Quilty LC, Bagby RM. An Examination of the Topology and Measurement of the Alexithymia Construct Using Network Analysis. J Pers Assess. 2016;98:649-59.

30. Taylor GJ, Bagby RM PJ. Disorders of Affect Regulation: Alexithymia in medical and psychiatric illness. Cambridge, UK, Cambridge University Press; 1997.

31. Luquet P. Le changement dans la mentalisation. Rev Français Psychanal 1981;45:1023-28.

32. Lecours S, Bouchard M-C. Dimensions of mentalization: Outlining levels of psychic transformation. Int J Psychoanal psychoanalysis. 1997;78:855-75.
33. Lane RD, Schwartz GE. Levels of emotional awareness: a cognitive-developmental theory and its application to psychopathology. Am J Psychiatry. 1987;144:133-43.

34. Fonagy P, Target M. Attachment and reflective function: their role in self-organization. Dev Psychopathol. 1997;9:679-700.

35. Fonagy P, Gergely G, Jurist EL, Target M. Affect Regulation, Mentalization, and the development of the Self. Other Press, New York; 2002.

36. Fonagy P, Bateman AW, Luyten P. Introduction and overview. In: Bateman AW, Fonagy P, editors. Handbook of Mentalization in Mental Health Practice. Washington DC: American Psychiatric Publishing; 2012. p. 3-42.

37. Lane RD, Weihs KL, Herring A, Hishaw A, Smith R. Affective agnosia: Expansion of the alexithymia construct and a new opportunity to integrate and extend Freud's legacy. Neurosci Biobehav Rev. 2015;55:594-611.

38. Lane RD, Hsu C-HH, Locke DEC, Ritenbaugh C, Stonnington CM. Role of theory of mind in emotional awareness and alexithymia: Implications for conceptualization and measurement. Conscious Cogn. 2015;33:398-405.

39. Vanheule S, Meganck R, Desmet M. Alexithymia, social detachment and cognitive processing. Psychiatry Res. 2011;190:49-51.

40. Vanheule S, Verhaeghe P, Desmet M. In search of a framework for the treatment of alexithymia. Psychol Psychother Theory, Res Pract; 2010;84:84-97.

41. Taylor GJ, Bagby RM, Parker JDA. What's in the name 'alexithymia'? A commentary on 'Affective agnosia: Expansion of the alexithymia construct and a new opportunity to integrate and extend Freud's legacy.'. Neurosci Biobehav Rev 2016;68:1006-20.

42. Luyten P, Fonagy P. The neurobiology of mentalizing. Personal Disord 2015;6:366-79.

43. Lane RD, Weihs KL, Herring A, Hishaw A, Smith R. Affective agnosia: Expansion of the alexithymia construct and a new opportunity to integrate and extend Freud's legacy. Neurosci Biobehav Rev. 2015;55:594-611.

44. Grynberg D, Luminet $O$, Corneille $O$, Grèzes J, Berthoz S. Alexithymia in the interpersonal domain: A general deficit of empathy? Pers Individ Dif. 2010;49:845-50 
45. Decety J, Moriguchi Y. The empathic brain and its dysfunction in psychiatric populations: implications for intervention across different clinical conditions. Biopsychosoc Med. 2007;1:22.

46. Taylor GJ, Bagby RM. An overview of the alexithymia construct. In: The handbook of emotional intelligence; 2000. p. 40-67.

47. Primmer J. Understanding the dimensional nature of alexithymia. J Conscious Stud. 2013;20:111-31.

48. Krystal H. Desomatization and the consequences of infantile psychic trauma. Psychoanal Inq A Top J Ment Heal Prof. 1997;17:126-50.

49. Karukivi M, Saarijärvi S. Development of alexithymic personality features. World J psychiatry. 2014;4:91-102.

50. Keefer K V, Taylor GJ, Parker JDA, Bagby RM. Taxometric Analysis of the Toronto Structured Interview for Alexithymia : Further Evidence That Alexithymia Is a Dimensional Construct. 2019;26:364-374

51. Parker JDA, Keefer KV, Taylor GJ, Bagby RM. Latent structure of the alexithymia construct: a taxometric investigation. Psychol Assess. 2008;20:38596.

52. Mattila AK, Saarni SI, Alanen E, Salminen JK, Kronholm E, Jula A, et al. Health-related qualityof-life profiles in nonalexithymic and alexithymic subjects from general population. J Psychosom Res. 2010;68:279-83.

53. Freyberger H. Supportive psychotherapeutic techniques in primary and secondary alexithymia. Psychother Psychosom 1977;28:337-42.

54. Lumley MA, Neely LC, Burger AJ. The assessment of alexithymia in medical settings: implications for understanding and treating health problems. J Pers Assess 2007;89:230-46.

55. Fava GA. The Psychosomatic Legacy: A Tribute to Hellmuth Freyberger, MD (1923-2012). Psychother Psychosom. 2013;82:201-3.

56. Grandi S, Sirri L, Wise TN, Tossani E, Fava GA. Kellner's emotional inhibition scale: a clinimetric approach to alexithymia research. Psychother Psychosom 2011;80:335-44.

57. Wise TN, Mann LS, Mitchell JD, Hryvniak M, Hill B. Secondary alexithymia: an empirical validation. Compr Psychiatry 1990;31:284-8.

58. Nemiah JC. Alexithymia: Theoretical considerations. Psychother Psychosom. 1977;28:199-206.
59. Sifneos PE. Affect deficit and alexithymia. New Trends Exp Clin Psychiatry; 1994;10:193-95.

60. Knapp P. Emotions and bodily changes: A reassessment. In: Temoshok L, Dyke C, Zegans LS, editors. Emotions in Health and Illness: Theoretical and Research Foundations. New York: Grune \& Stratton; 1983. p. 15-27.

61. Krystal H. Alexithymia and the effectiveness of psychoanalytic treatment. Int J Psychoanal Psychother. 1982;9:353-78.

62. McDougall J. Alexithymia, psychosomatosis, and psychosis. Int J Psychoanal Psychother. 1982;9:379-88.

63. McDougall J. Theaters of the body: A psychoanalytic approach to psychosomatic illness. Norton, New York; 1989.

64. Margulies A. Human Feelings: Explorations in Affect Development and Meaning. In: Ablon SL, Brown D, Khantzian EJ, Mack JE, editors. Human feelings: Explorations in affect development and meaning. New York: Analytic Press, Hillsdale; 1993. p. 181-202.

65. Luminet O, Rokbani L, Ogez D, Jadoulle V. An evaluation of the absolute and relative stability of alexithymia in women with breast cancer. J Psychosom Res. 2007;62:641-8

66. Marchesi C, Giaracuni G, Paraggio C, Ossola P, Tonna M, De Panfilis C. Pre-morbid alexithymia in panic disorder: a cohort study. Psychiatry Res 2014;215:141-5.

67. Fonagy P, Bateman A, Bateman A. The widening scope of mentalizing: A discussion. Psychol Psychother Theory, Res Pract 2011;84:98-110.

68. Luminet O, Bagby RM, Taylor GJ. An evaluation of the absolute and relative stability of alexithymia in patients with major depression. Psychother Psychosom. 2001;70:254-60

69. Stingl M, Bausch S, Walter B, Kagerer S, Leichsenring F, Leweke F. Effects of inpatient psychotherapy on the stability of alexithymia characteristics. J Psychosom Res. 2008;65:173-80.

70. Taylor GJ, Bagby M, Parker JDA. The Revised Toronto Alexithymia Scale: Some Reliability, Validity, and Normative Data. Psychother Psychosom. 1992;57:34-41.

71. Haviland MG. Alexithymia. In: Encyclopedia of Mental Health. Elsevier; 2016. p. 47-53. 
72. Vorst HC, Bermond B. Validity and reliability of the Bermond-Vorst Alexithymia Questionnaire. Pers Individ Dif. 2001;30:413-34.

73. Vanheule S, Meganck R, Desmet M. Alexithymia, social detachment and cognitive processing. Psychiatry Res. 2011;190:49-51.

74. Taylor GJ, Bagby RM, Luminet O. Assessment of Alexithymia: self-report and observer-rated measures. In: Bar-On R, Parker JDA, editors. The handbook of emotional intelligence. Jossey-Bass, San Francisco; 2000. p. 301-19.

75. Watters CA, Taylor GJ, Bagby RM. Illuminating the theoretical components of alexithymia using bifactor modeling and network analysis. Psychol Assess 2016;28:627-38.

76. Timoney LR, Holder MD. Recommendations for Measurement. In: Emotional Processing Deficits and Happiness. Springer, Dordrecht; 2013. p. 35-39.

77. Taylor GJ, Bagby RM. The alexithymia personality dimension. In: Widiger TA, editor. The Oxford handbook of personality disorders. New York: NY: Oxford University Press; 2012. p. 648-73.

78. Fava GA, Freyberger HJ, Bech P, Christodoulou G, Sensky T, Theorell T, et al. Diagnostic criteria for use in psychosomatic research. Psychother Psychosom. 1995;63:1-8.

79. Krystal JH, Giller EL, Cicchetti DV. Assessment of alexithymia in posttraumatic stress disorder and somatic illness: introduction of a reliable measure. Psychosom Med. 1986;48:84-94.

80. Weinryb RM, Rössel RJ. Karolinska Psychodynamic Profile. KAPP. Acta Psychiatr Scand. 1991;363(Suppl):1-23.

81. Lane RD, Ahern GL, Schwartz GE, Kaszniak AW. Is alexithymia the emotional equivalent of blindsight? Biol Psychiatry 1997;42:834-44.

82. Lane RD, Sechrest L, Riedel R. Sociodemographic correlates of Alexithymia. Compr Psychiatry. 1998;39:377-85.

83. Bornstein RF, O’Neill RM. Construct validity of a self-report measure of alexithymia in a psychiatric inpatient sample. J Clin Psychol 1993;49:841-6.

84. Kleiger JH, Kinsman RA. The development of an MMPI alexithymia scale. Psychother Psychosom 1980;34:17-24.

85. Bagby RM, Taylor GJ, Atkinson L. Alexithymia: a comparative study of three self-report measures. J Psychosom Res 1988;32:107-16.
86. Martin JB, Pihl RO, Dobkin P. Schalling-Sifneos Personality Scale: Findings and Recommendations. Psychother Psychosom. 1984;41:145-52.

87. Sifneos PE. The Schalling-Sifneos personality scale revised. Psychother Psychosom. 1986;45:161-65.

88. Bermond B, Vorst HC, Vingerhoets AJ, Gerritsen W. The Amsterdam Alexithymia Scale: its psychometric values and correlations with other personality traits. Psychother Psychosom. 1999;68:241-51.

89. Sifneos PE. The prevalence of 'alexithymic' characteristics in psychosomatic patients. Psychother Psychosom. 1973;22:255-62.

90. Sriram TG, Pratap L, Shanmugham V. Towards Enhancing the Utility of Beth Israel Hospital Psychosomatic Questionnaire. Psychother Psychosom. 1988;49:205-11.

91. Bagby RM, Taylor GJ, Parker JDA, Dickens SE. The development of the Toronto Structured Interview for Alexithymia: item selection, factor structure, reliability and concurrent validity. Psychother Psychosom. 2006;75:25-39.

92. Krystal H. Integration and self-healing: Affect, trauma, alexithymia. Analytic Press; 1988.

93. Tibon S, Weinberger Y, Handelzalts JE, Porcelli P. Construct validation of the Rorschach RealityFantasy Scale in alexithymia. Psychoanal Psychol. 2005;22:508-23.

94. Porcelli P, Mihura JL. Assessment of alexithymia with the Rorschach Comprehensive System: the Rorschach Alexithymia Scale (RAS). J Pers Assess 2010;92:128-36.

95. Acklin MW, Alexander G. Alexithymia and somatization. A Rorschach study of four psychosomatic groups. J Nerv Ment. Dis 1988;176:343-50.

96. Bertagne P, Pedinielli JL, Marliere C. [Alexithymia. Evaluation, quantitative and clinical data]. Encephale 1992;18:121-30.

97. Cohen K, Auld F, Demers L, Catchlove R. Alexithymia. The development of a valid and reliable projective measure (the objectively scored Archetypal Test). J Nerv Ment Dis 1985;173:621-7.

98. Haviland MG, Reise SP. A California Q-set alexithymia prototype and its relationship to egocontrol and ego-resiliency. J Psychosom Res 1996;41:597-607.

99. Haviland MG, Sonne JL, Kowert PA. Alexithymia and psychopathy: comparison and application of California Q-set Prototypes. J Pers Assess 2004;82:306-16. 
100. Haviland MG. The validity of the California Q-set Alexithymia Prototype. Psychosomatics 1998;39:536-9.

101. Haviland MG, Louise Warren W, Riggs ML. An Observer Scale to Measure Alexithymia. Psychosomatics. 2000;41:385-92.

102. Lane RD, Quinlan DM, Schwartz GE, Walker PA, Zeitlin SB. The Levels of Emotional Awareness Scale: A Cognitive-Developmental Measure of Emotion. J Pers Assess 1990;55:124-34.

103. Maroti D, Lilliengren P, Bileviciute-Ljungar I. The Relationship Between Alexithymia and Emotional Awareness: A Meta-Analytic Review of the Correlation Between TAS-20 and LEAS. Front Psychol. 2018;16;9.

104. Taylor GJ, Ryan D, Bagby RM. Toward the development of a new self-report alexithymia scale. Psychother Psychosom. 1985;44:191-9.

105. Kooiman C, Spinhoven P, Trijsburg R. The assessment of alexithymia. J Psychosom Res. 2002;53:1083-90.

106. Lovko SK, Gelo J, Karlović D. Validation study of the Toronto Alexithymia Scale (TAS-26) in Croatian population. Acta Clin Croat. 2015;54:272-8.

107. Bagby RM, Parker JDA, Taylor GJ. The twentyitem Toronto Alexithymia scale-I. Item selection and cross-validation of the factor structure. J Psychosom Res 1994;38:23-32.

108. Taylor GJ, Bagby RM, Parker JDA. The 20-Item Toronto Alexithymia Scale. IV. Reliability and factorial validity in different languages and cultures. J Psychosom Res. 2003;55:277-83.

109. Trajanović NN, Djurić V, Latas M, Milovanović S, Jovanović AA, Djurić D. Serbian translation of the 20-item Toronto Alexithymia Scale: psychometric properties and the new methodological approach in translating scales. Srp Arh Celok Lek 2013;141:366-70.

110. Pinaquy S, Chabrol H, Barbe P. [Factorial analysis and internal consistency of the French version of the Toronto Alexithymia Scale (TAS 20), in obese women]. Encephale 2002;28:277-82.
111. Ling Y, Zeng Y, Yuan H, Zhong M. Cross-cultural validation of the 20 -item Toronto Alexithymia Scale in Chinese adolescents. J Psychiatr Ment Health Nurs 2016;23:179-87.

112. Marchesi C, Ossola P, Tonna M, De Panfilis C. The TAS-20 more likely measures negative affects rather than alexithymia itself in patients with major depression, panic disorder, eating disorders and substance use disorders. Compr Psychiatry. 2014;55:972-8.

113. Bagby RM, Taylor GJ, Parker JD. The Twentyitem Toronto Alexithymia Scale--II. Convergent, discriminant, and concurrent validity. J Psychosom Res. 1994;38:33-40.

114. Henry JD, Phillips LH, Maylor EA, Hosie J, Milne AB, Meyer C. A new conceptualization of alexithymia in the general adult population: implications for research involving older adults. J Psychosom Res. 2006; 60:535-43.

115. Rokvić N, Jovanović T. Aleksitimija merena TAS20 upitnikom: provera faktorske strukture upitnika i njenog odnosa sa zadovoljstvom životom i Velikih pet dimenzija ličnosti. Psihol istraživanja. 2018;21:23-40.

116. Keefer K V. Self-Report Assessments of Emotional Competencies. J Psychoeduc Assess. 2015;33:3-23.

117. Mansbridge J. Skin substitutes to enhance wound healing. Expert Opin Investig Drugs. 1998;7:8039.

118. Taylor GJ, Parker JD, Bagby RM, Bourke MP. Relationships between alexithymia and psychological characteristics associated with eating disorders. J Psychosom Res. 1996;41:561-8.

119. Vanheule S. Challenges for alexithymia research: a commentary on 'The construct of alexithymia: associations with defense mechanisms'. J Clin Psychol. 2008;64:332-7.

120. Kušević Z, Marušić K. The relationship between alexithymia and morbidity. Liječ Vjesn. 2014;36:44-8. 


\section{Korijeni aleksitimije}

Sažetak- Ovaj pregledni rad predstavlja povijesnu pozadinu i teorijski okvir koncepta te razvoj instrumenata koji mjere aleksitimiju. Koncept aleksitimije proizašao je iz kliničkog promatranja, bez prethodno osmišljenog teorijskog okvira. Danas je aleksitimija dio kognitivne teorije i teorije regulacije afekta. Aleksitimija je pobudila veliko zanimanje psihoanalitičara, kao i kliničara drugih teorijskih usmjerenja. Koncept je nastao iz kliničkih iskustava sa psihosomatskim bolesnicima kod kojih je uočen nezadovoljavajući odgovor na psihoterapiju. U ovom radu opisujemo razvoj od kategorijskog do dimenzijskog koncepta aleksitimije. Aleksitimija se može razumjeti kao obrambeni mehanizam, ali i kao patologija deficita. Preklapa se s konceptom mentalizacije. Mogu se razlikovati njene state i trait karakteristike. U završnom dijelu članka navedeni su svi instrumenti za mjerenje aleksitimije.

Ključne riječi: aleksitimija, psihoanalitička teorija, psihosomatske bolesti, teorija uma, mentalizacija 